\title{
Observations and analysis of organic aerosol evolution in some prescribed fire smoke plumes
}

\author{
A. A. May ${ }^{1, *}$, T. Lee ${ }^{1, * *}$, G. R. McMeeking ${ }^{1, * * *}$, S. Akagi ${ }^{2}$, A. P. Sullivan ${ }^{1}$, S. Urbanski ${ }^{3}$, R. J. Yokelson ${ }^{2}$, and \\ S. M. Kreidenweis ${ }^{1}$ \\ ${ }^{1}$ Department of Atmospheric Science, Colorado State University, Fort Collins, CO, USA \\ ${ }^{2}$ Department of Chemistry, University of Montana, Missoula, MT, USA \\ ${ }^{3}$ Missoula Fire Sciences Laboratory, Rocky Mountain Research Station, US Forest Service, Missoula, MT, USA \\ * now at: Department of Civil, Environmental and Geodetic Engineering, The Ohio State University, Columbus, OH, USA \\ ** now at: Department of Environmental Science, Hankuk University of Foreign Studies, Yongin, Korea \\ *** now at: Droplet Measurement Technologies, Boulder, CO, USA
}

Correspondence to: A. A. May (may.561@osu.edu) and S. M. Kreidenweis (sonia@atmos.colostate.edu)

Received: 12 December 2014 - Published in Atmos. Chem. Phys. Discuss.: 21 January 2015

Revised: 11 May 2015 - Accepted: 12 May 2015 - Published: 11 June 2015

\begin{abstract}
Open biomass burning is a significant source of primary air pollutants such as particulate matter (PM) and non-methane organic gases (NMOG). However, the physical and chemical atmospheric processing of these emissions during transport is poorly understood. Atmospheric transformations of biomass burning emissions have been investigated in environmental chambers, but there have been limited opportunities to investigate these transformations in the atmosphere. In this study, we deployed a suite of real-time instrumentation on a Twin Otter aircraft to sample smoke from prescribed fires in South Carolina, conducting measurements at both the source and downwind to characterize smoke evolution with atmospheric aging. Organic aerosol (OA) within the smoke plumes was quantified using an aerosol mass spectrometer (AMS); refractory black carbon (rBC) was quantified using a single-particle soot photometer, and carbon monoxide $(\mathrm{CO})$ and carbon dioxide $\left(\mathrm{CO}_{2}\right)$ were measured using a cavity ring-down spectrometer. During the two fires for which we were able to obtain aerosol aging data, normalized excess mixing ratios and "export factors" of conserved species $\left(\mathrm{rBC}, \mathrm{CO}, \mathrm{CO}_{2}\right)$ suggested that changes in emissions at the source did not account for most of the differences observed in samples of increasing age. An investigation of AMS mass fragments indicated that the in-plume fractional contribution $\left(f_{m / z}\right)$ to OA of the primary fragment $(m / z 60)$ decreased downwind, while the fractional contribution of the secondary fragment $(\mathrm{m} / z 44)$ increased. Increases in $f_{44}$ are
\end{abstract}

typically interpreted as indicating chemical aging of OA. Likewise, we observed an increase in the $\mathrm{O}: \mathrm{C}$ elemental ratio downwind, which is usually associated with aerosol aging. However, the rapid mixing of these plumes into the background air suggests that these chemical transformations may be attributable to the different volatilities of the compounds that fragment to these $m / z$ in the AMS. The gas-particle partitioning behavior of the bulk OA observed during the study was consistent with the predictions from a parameterization developed for open biomass burning emissions in the laboratory. Furthermore, we observed no statistically significant increase in total organic mass with atmospheric transport. Hence, our results suggest that dilution-driven evaporation likely dominated over the chemical production of secondary organic aerosol (SOA) within our smoke plumes, presumably due to the fast dilution and limited aging times $(<\sim 5 \mathrm{~h})$ that we could sample.

\section{Introduction}

Open biomass burning is estimated to be the largest contributor to atmospheric fine carbonaceous particulate matter (PM) (Bond et al., 2013) and the second largest contributor to atmospheric non-methane organic gases (NMOG) on a global scale (Akagi et al., 2011). Substantial research has been focused on characterizing gas- and particle-phase pri- 
mary emissions from biomass burning and the development of emission inventories (Akagi et al., 2011; Burling et al., 2010, 2011; Christian et al., 2003; Hosseini et al., 2013; May et al., 2014; McMeeking et al., 2009; Reid et al., 2005; Urbanski, 2013; Urbanski et al., 2011; Watson et al., 2011; van der Werf et al., 2010; Wiedinmyer et al., 2006, 2011; Yokelson et al., 2013). These emissions are ultimately integrated into chemical transport models used to predict regional air quality and global climate impacts.

Organic aerosol (OA) species represent the major component by mass in the submicron carbonaceous PM emitted from fires (May et al., 2014; McMeeking et al., 2009; Reid et al., 2005). In general, the physical and chemical evolution of biomass-burning-derived $\mathrm{OA}$ in the atmosphere after emission is poorly understood, in part because OA is a "metastable intermediate" (Donahue et al., 2013). Since OA consists of thousands of species with a spectrum of temperature-dependent saturation vapor pressures, the portion of OA that is observable as PM varies with dilution and with atmospheric temperature. Further, many of the species comprising OA have been shown to undergo oxidation reactions, forming secondary products with their own range of volatilities. In field studies, OA in biomass burning plumes has been observed to be enhanced, be depleted, or remain constant with time after emission (Akagi et al., 2012; Capes et al., 2008; Cubison et al., 2011; DeCarlo et al., 2008; Jolleys et al., 2012, 2015; Vakkari et al., 2014; Yokelson et al., 2009), but due to the complexities described above, the attribution of these transformations to specific physical and chemical processes is difficult (Heilman et al., 2014).

Laboratory studies have been conducted to attempt to separate these processes for biomass-burning-derived OA. As part of the third Fire Lab at Missoula Experiment (FLAMEIII), May et al. (2013) derived a volatility distribution and related thermodynamic parameters representative of the primary emissions from all of the biomass fuels studied. In that same study, Hennigan et al. (2011) and Ortega et al. (2013) investigated chemical transformations of the emissions using an environmental chamber and an oxidative flow reactor, respectively. Results from these experiments demonstrated that the OA mass can be enhanced, depleted, or remain roughly constant with oxidation, similar to field measurements, yet the OA always became apparently more oxidized with photochemical aging, as interpreted from the organic mass fragments measured via online aerosol mass spectrometry.

In this work, we report and interpret observations from the South Carolina fiRe Emissions And Measurements (SCREAM) campaign conducted in October-November 2011 (Akagi et al., 2013, 2014; May et al., 2014; Sullivan et al., 2014). The objectives of SCREAM were to (1) simulate moderately intense wildfires by conducting prescribed burns at sites with high fuel loadings, (2) characterize the emissions and develop estimates of emission factors and emission ratios from both ground- and aircraft-based sampling, and (3) sample plumes downwind as they evolved during atmospheric transport. We also sampled fires of opportunity during the study. The SCREAM campaign combined simultaneous aircraft-based online measurements of refractory black carbon (rBC), time-resolved non-refractory submicron PM measurements (including OA), and time-resolved watersoluble organic carbon (WSOC) and levoglucosan (LEV) measurements in addition to a suite of gas-phase compounds. Companion papers have reported airborne trace gas emissions (Akagi et al., 2013), ground-based trace gas emissions (Akagi et al., 2014), airborne WSOC and smoke marker emissions (Sullivan et al., 2014), and airborne primary PM emissions (May et al., 2014). This paper focuses on airborne observations of the OA mass concentrations and composition near the source and the transformations of OA mass concentration and composition during the first hours of atmospheric transport.

\section{Methods}

Emissions from five of the seven fires sampled during SCREAM are discussed in this paper. Details including fuel type, area burned, meteorology, and stand history were provided by Akagi et al. (2013) and are summarized briefly here. Two of the burns were conducted on the Fort Jackson (FJ) army base (located northeast of Columbia, SC) in Blocks 9b (FJ 9b; 34 ${ }^{\circ} 0^{\prime} 15^{\prime \prime} \mathrm{N}, 80^{\circ} 52^{\prime} 37^{\prime \prime} \mathrm{W} ; 1$ November 2011) and 22b (FJ 22b; 34 $5^{\prime} 4^{\prime \prime}$ N, 80 $52^{\prime} 16^{\prime \prime} \mathrm{W} ; 2$ November 2011). These burns occurred in older stands that had not been treated for a number of years and were intended to simulate wildfires. Fuel inventories indicated that the vegetation was comprised primarily of mature longleaf pine (Pinus palustris) and loblolly pine (Pinus taeda) with some contributions from turkey oak (Quercus laevis Walter) and farkleberry (Vaccinium arboretum Marsh.). Complementary ground-based measurements of emissions from the FJ burns were reported by Akagi et al. (2014). The three other sampled fires were designated Georgetown $\left(33^{\circ} 12^{\prime} 9^{\prime \prime} \mathrm{N}, 79^{\circ} 24^{\prime} 6^{\prime \prime} \mathrm{W} ; 7\right.$ November 2011), Francis Marion $\left(33^{\circ} 12^{\prime} 55^{\prime \prime} \mathrm{N}, 7^{\circ} 28^{\prime} 34^{\prime \prime} \mathrm{W}\right.$; 8 November 2011), and Bamberg ( $33^{\circ} 14^{\prime} 5^{\prime \prime} \mathrm{N}, 80^{\circ} 56^{\prime} 41^{\prime \prime} \mathrm{W}$; 10 November 2011), based on the location in SC where the fire occurred. Georgetown and Francis Marion were located in coastal SC, likely burning coastal grasses and longleaf pine understory, respectively, a conclusion which is based on in-flight observations. The Bamberg fire, located roughly $80 \mathrm{~km}$ due south of the Fort Jackson site in inland SC, was likely comprised of multiple fuel types, including longleaf and loblolly pine understory as well as marsh grasses, as indicated by smoke marker ratio measurements reported in Sullivan et al. (2014).

\subsection{Sample collection}

Smoke plumes during SCREAM were sampled via airborne measurements onboard a United States Forest Service DHC- 


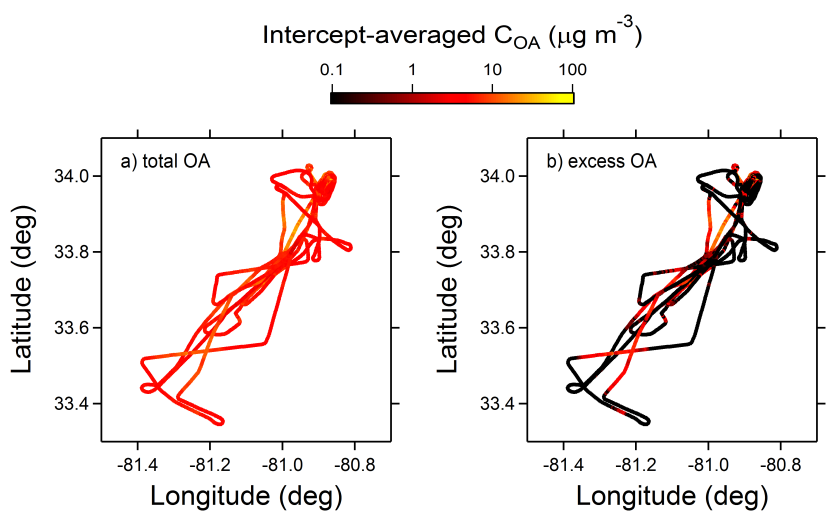

Figure 1. Flight tracks colored by (a) total OA concentration and (b) excess OA concentration. Due to the log scaling of intercept-averaged concentrations, the minimum value in (b) is set to $0.1 \mu \mathrm{g} \mathrm{m}^{-3}$. Removing the background $\mathrm{OA}$ elucidates distinct plume transport to the southwest.

6 Twin Otter aircraft. Sampling strategies and flight tracks are described in prior literature from the SCREAM study (Akagi et al., 2013; May et al., 2014; Sullivan et al., 2014). Fires were initiated in midmorning, and the aircraft initially sampled the emissions near the source. Following the source characterization period, the downwind plume was sampled to investigate the effect of chemical and physical aging during atmospheric transport. For consistency with May et al. (2014), we defined "near-source" samples as those collected within $5 \mathrm{~km}$ of the fire (always less than $30 \mathrm{~min}$ of aging, but most of the smoke had an age $<10$ min based on average ambient wind speed), while downwind samples were those collected at distances greater than $5 \mathrm{~km}$. During flights, there were also periods of out-of-plume (i.e., background) sampling to establish time-dependent background concentrations of the species that were quantified in the plume.

The flight path for the FJ $9 \mathrm{~b}$ burn is provided in Fig. 1 as one example. Figure 1a provides the total (i.e., not background-corrected) $\mathrm{OA}$ mass concentration $\left(C_{\mathrm{OA}}\right)$, which was typically between $3-7 \mu \mathrm{g} \mathrm{m}^{-3}$ (average $=4.6 \mu \mathrm{g} \mathrm{m}^{-3}$ ) outside of the plume throughout the sampling domain, with the exception of higher concentrations attributable to the smoke plume. Correcting the data for the background OA results in Fig. 1b; here, the plume transport is more distinct.

The first $1-2 \mathrm{~h}$ of flight time was typically spent sampling near the source at $\sim 100-600 \mathrm{~m}$ altitude. Following this characterization period, it was possible to sample smoke downwind with $1-2 \mathrm{~h}$ of atmospheric aging, so we then alternated downwind cross-plume samples with occasional additional source sampling. A challenge was that emissions were rapidly diluted and mixed within the boundary layer, and the plumes did not penetrate into the free troposphere, so visual tracking of the plumes was challenging. In fact, the flight path was guided via consultation with real-time instrument output, which enabled the identification of plume center and extent as well as the marking of way points. Furthermore, the plume from the FJ 22b fire entered restricted air space near Columbia, SC, so it was only possible to follow this plume for a short distance from the point of emission.

Downwind, the Twin Otter typically flew at altitudes between 500 and $1500 \mathrm{~m}$, but not with sufficient detail to develop vertical profiles. All data, regardless of sampling altitude (or latitude and longitude), are categorized as "within the plume" or "outside of the plume" along with the additional distinction of "estimated time since emission" (please refer to Sect. 2.3.1).

\subsection{Instrumentation}

The instrumentation installed on the Twin Otter used to characterize emissions included a high-resolution time-of-flight aerosol mass spectrometer (HR-ToF-AMS; Aerodyne Research, Inc.), a single-particle soot photometer (SP2; Droplet Measurement Technologies, Inc.), a cavity ring-down spectrometer (CRDS; Picarro G2401; Picarro, Inc.), an airborne Fourier-transform infrared spectrometer (AFTIR), a particleinto-liquid sampler/total organic carbon and fraction collector system (Sullivan et al., 2014), and an aircraft integrated meteorological measuring system (AIMMS-20) probe (Aventech Research, Inc.). The AIMMS-20 provided meteorological data such as three-dimensional wind vectors, threedimensional position of the aircraft (i.e., latitude, longitude, and altitude), ambient temperature, and ambient relative humidity. All sampling was conducted from a low-turbulence inlet (Wilson et al., 2004) followed by a nonrotating microorifice uniform deposit impactor (MOUDI; Marple et al., 1991). The MOUDI was operated such that it served as a $\mathrm{PM}_{1}$ selector (i.e., having $50 \%$ particle transmission efficiency for particulate matter of $1 \mu \mathrm{m}$ aerodynamic diameter with a sharpness of 1.08 - particles less than roughly $900 \mathrm{~nm}$ will be transmitted with $100 \%$ efficiency). All data were adjusted to the same timestamp via the alignment of peaks (thus accounting for differences in both instrument clocks and instrument response times), which we referenced to the HRToF-AMS.

\subsubsection{Aerosol mass spectrometer}

The HR-ToF-AMS (hereafter AMS) characterizes nonrefractory submicron aerosol by focusing sampled particles through an aerodynamic lens, collecting particles on a thermal vaporizer, ionizing the vaporized particles via electron impaction, and detecting ions $(\mathrm{m} / \mathrm{z})$ in the high-resolution time-of-flight mass spectrometer (DeCarlo et al., 2006). Using the ToF-AMS data analysis toolkit SQUIRREL/PIKA (SeQUential Igor data RetRiEvaL/Peak Integration by Key Analysis; Sueper et al., 2013), aerosol mass concentrations can be reconstructed from the $m / z$ signal; for this study, we fit HR peaks for $m / z \leq 200$. These concentrations are dependent on instrument parameters (e.g., ionization efficiency and 
vaporizer collection efficiency). Ionization efficiency calibrations were performed with $350 \mathrm{~nm}$ ammonium nitrate particles throughout the campaign, with values ranging from $1.83 \times 10^{-7}$ to $2.91 \times 10^{-7}$ ions molecule ${ }^{-1}$. Compositiondependent collection efficiencies were calculated following the algorithm of Middlebrook et al. (2012), which is now built into the SQUIRREL software, for each AMS sample and ranged from roughly 0.5 to 0.9 , with a campaign-average value of 0.53. We report AMS-derived emissions data of nitrate, sulfate, ammonium, and chloride elsewhere (May et al., 2014). As stated in May et al. (2014), our results are potentially biased by up to a factor of 2 due to the inherent uncertainty in our estimation of CE.

The AMS was mounted into National Center for Atmospheric Research GV-type aircraft racks with a pressurecontrolled inlet to reduce fluctuations in the pressure within the aerodynamic lens (Bahreini et al., 2008). During operation, data were exclusively collected using the "V-mode" of the ion time of flight within the mass spectrometer; since no particle time-of-flight data were collected, no size-resolved information is available. AMS data were typically collected with a time resolution of $6 \mathrm{~s}$ (corresponding to a flight distance of roughly $250-300 \mathrm{~m}$ ).

While we obtained simultaneous measurements of gasphase $\mathrm{CO}_{2}$, we utilized the standard correction in the fragmentation table from Allan et al. (2004), rather than explicit corrections for $\mathrm{CO}_{2}$ to account for differences within and without the plume. The AMS samples particles roughly $10^{7}$ times more efficiently than the gas phase. We estimate that, on average, our plume OA concentrations are positively biased by $0.0044 \pm 0.0019 \%$ (both near the source and downwind), our background OA concentrations are positively biased by $0.025 \pm 0.021 \%$, and our $m / z 44$ measurements are positively biased by $0.20 \pm 0.11 \%$, all based on colocated gas-phase $\mathrm{CO}_{2}$ measurements. Consequently, we deemed this correction unnecessary as this interference represents $<0.5 \%$ of our reported values.

\subsubsection{Single-particle soot photometer}

The SP2 provides operationally defined $\mathrm{rBC}$ mass concentrations via laser-induced incandescence (Stephens et al., 2003; Schwarz et al., 2006). Absorbing material present in particles is heated to its vaporization temperature and emits radiation, which is measured by optical detectors. This approach removes uncertainties due to interferences of artifacts that have been observed during filter-based approaches (Kirchstetter et al., 2004) and excludes the influence of "brown" carbon that can bias optical absorption methods (Andreae and Gelencsér, 2006; Lack et al., 2012), although it has been shown that the method responds to some metals. Signal is related to rBC mass via calibration procedures; during SCREAM, calibrations were performed using fullerene soot. Generally, rBC mass concentrations were recorded every $6 \mathrm{~s}$, similar to the
AMS. Additional details related to the SP2 operation during this campaign can be found in May et al. (2014).

\subsubsection{Cavity ring-down spectrometer}

A Picarro G2401 provided $0.5 \mathrm{~Hz}$ measurements of $\mathrm{CO}_{2}$, $\mathrm{CO}, \mathrm{CH}_{4}$, and $\mathrm{H}_{2} \mathrm{O}$, which are the major gas-phase emissions from combustion sources. The CRDS was calibrated in-flight using mixed standards of $\mathrm{CO}_{2}, \mathrm{CO}$, and $\mathrm{CH}_{4}$ and procedures similar to those described by Urbanski (2013). These data were applied to calculate emission ratios and emission factors of particle-phase species, as described below.

\subsection{Data processing}

\subsubsection{Plume identification and age}

As discussed previously, visual plume identification was challenging. Positive downwind plume intercepts were confirmed through simultaneous spikes in measured values of $\mathrm{OA}, \mathrm{rBC}$, and $\mathrm{CO}$. These confirmed intercepts were corroborated by simultaneous increases in smoke markers (Sullivan et al., 2014) and trace gases (Akagi et al., 2013). Interceptaveraged concentrations for each transect were derived by integrating the excess area (above background) under the data time series curves and dividing by the elapsed time in the window of integration.

Sample ages (times since emission) were estimated using the distance from the source and average wind speed. Distance from the source was computed using the haversine formula and the spatial coordinates measured by the AIMMS20. Mean wind speed was also measured using the AIMMS20. Akagi et al. (2013) estimated that this approach has an uncertainty of roughly $30 \%$, largely due to uncertainties in the wind speed data. Due to the plume tracking challenges, plume intercepts were rarely perfectly perpendicular to the plume and were often diagonal transects. Thus, a given sample can be associated with a range of estimated ages. In subsequent figures, we plot the average age of a plume intercept along with error bars representing the range of ages; in these figures, we do not include the estimated uncertainty of $30 \%$ on this range.

In-plume data from all research flights were corrected for local background concentrations via integration under the curves in data time series between out-of-plume measurements. The resulting species concentrations are "excess" concentrations and are denoted by the delta symbol, i.e., $\Delta X$ is the excess concentration of species $X$. We show background values of some parameters in some of the following figures; these background concentrations represent the median background concentration for the duration of the given flight. Sample background-corrected data are provided in Fig. 1. 


\subsubsection{Excess emission ratios and emission factors}

Normalized excess mixing ratios (NEMR) are often used to account for transient fire behavior and the dilution and mixing of plumes with background air during transport (e.g., Hobbs et al., 2003) and are defined as

$\operatorname{NEMR}_{X}=\frac{\Delta X}{\Delta \mathrm{CO}}$,

where $\Delta X$ is the excess concentration of species $X$, and $\triangle \mathrm{CO}$ is the background-corrected value of CO. Since both numerator and denominator are excess quantities, uncertainties in their values increase as the plume dilutes and inplume concentrations approach the background concentrations. Here, we report plume-integrated $\operatorname{NEMR}_{X}$ for each plume interception, so our values differ from the "fireintegrated" values (based on a consideration of all the plume intercepts) reported in May et al. (2014). NEMR ${ }_{X}$ are reported here in units of $\mu \mathrm{g} \mathrm{m}^{-3} \mathrm{ppmv}^{-1} \mathrm{CO}$; this value can be converted to a mass mixing ratio (e.g., $\mathrm{g} \mathrm{g}^{-1} \mathrm{CO}$ ) by multiplying by a factor of $8.7 \times 10^{-4} \mathrm{ppmv} \mathrm{CO}\left(\mu \mathrm{g} \mathrm{CO} \mathrm{m}{ }^{-3}\right)^{-1}$. Strictly speaking, $\mathrm{NEMR}_{X}$ is a misnomer for aerosol mass concentrations, but we utilize this terminology for consistency with the vast body of prior literature.

Time series of instantaneous $\mathrm{NEMR}_{X}$ provide information on transient smoke behavior (Jolleys et al., 2014). By associating instantaneous $\mathrm{NEMR}_{X}$ with time since emission, physicochemical transformations can be investigated, since $\operatorname{NEMR}_{X}$ accounts for dilution and thus should be constant with time in the absence of sources or sinks of the species $X$ or changes in the initial emissions. The net formation of secondary organic aerosol (SOA) in smoke plumes can be inferred from an increase in NEMR $\mathrm{OA}_{\mathrm{OA}}$ with distance downwind (Yokelson et al., 2009). On the other hand, since the OA emitted from biomass burning sources is semi-volatile, the net evaporation of particle-phase mass as dilution proceeds would appear as a decrease in NEMR $\mathrm{NA}_{\mathrm{OA}}$ (Akagi et al., 2012).

Emission factors (EFs) are widely used descriptors of fire emissions (Ward and Radke, 1993; Andreae and Merlet, 2001). Their calculation relates the mass of $X$ emitted $\left(M_{X}\right)$ to the mass of dry fuel consumed $\left(M_{\text {fuel }}\right)$. In cases where the mass of fuel consumed is unknown, a carbon mass balance approach can be applied, which relates the change in the concentration of $X$ relative to the background $\left(\Delta X ; \mu \mathrm{g} \mathrm{m}^{-3}\right)$ to the excess carbon concentrations (i.e., background-corrected concentrations that have been converted to $\mathrm{mg} \mathrm{C} \mathrm{m}^{-3}$ ) of $\mathrm{CO}_{2}, \mathrm{CO}$, total organic gases ( $\left.\mathrm{TOG}=\mathrm{CH}_{4}+\mathrm{NMOG}\right)$, and carbonaceous $\mathrm{PM}\left(\mathrm{PM}_{\mathrm{C}}\right)$ :

$\mathrm{EF}_{X}=\frac{M_{X}}{M_{\text {fuel }}}=\frac{\Delta X}{\Delta \mathrm{CO}_{2}+\Delta \mathrm{CO}+\Delta \mathrm{TOG}+\Delta \mathrm{PM}_{\mathrm{C}}} f_{\mathrm{C}}$.

In Eq. (2), the term $f_{\mathrm{C}}$ is a conversion factor representing fuel carbon content. Since we lack detailed fuel information, we assume that $f_{\mathrm{C}}=0.50$, roughly the average fuel carbon content of southeastern (SE) US coastal plain biomass fuels reported in laboratory studies (Burling et al., 2010; May et al., 2014; McMeeking et al., 2009). For convenience and since $\Delta \mathrm{TOG}$ and $\Delta \mathrm{PM}_{\mathrm{C}} \ll\left(\Delta \mathrm{CO}_{2}+\Delta \mathrm{CO}\right)$, we approximate $\mathrm{EF}_{X}$ neglecting both $\triangle \mathrm{TOG}$ and $\Delta \mathrm{PM}_{\mathrm{C}}$, which results in an overestimate of $\mathrm{EF}_{X}$ by $\sim 3-5 \%$ (Yokelson et al., 2013). Like $\operatorname{NEMR}_{X}, \mathrm{EFs}_{X}$ are based on excess concentrations and account for dilution, but if an "emission factor" is computed with downwind data, the value obtained reflects changes in the initial emission factor plus the effect of any sources or sinks of the originally emitted species $X$. Hereafter, we will refer to downwind "emission factors" as "export factors" but will continue to use the abbreviation $\mathrm{EF}_{X}$, with export factors also being calculated from Eq. (2); the main distinction is that an export factor describes $X$ downwind from the source, and thus may be subject to both changes in the emissions as the fire burns and atmospheric transformations. We report $\mathrm{EF}_{X}$ as grams or milligrams $\mathrm{kg}^{-1}$ dry fuel.

\section{Results and discussion}

During the study, only two fires provided adequate downwind aerosol data to allow us to investigate in-plume aerosol physicochemical transformations: the FJ 9b fire and the Francis Marion fire. As mentioned earlier, the plume from the FJ $22 b$ fire entered restricted airspace and could not be pursued. Further, the Georgetown fire was a small fire whose plume rapidly mixed with the background, so downwind $\triangle \mathrm{OA}$ was small and uncertain; the Bamberg samples represented two distinct fuel types as shown elsewhere (May et al., 2014; Sullivan et al., 2014), making it difficult to distinguish aerosol transformations during transport from differences in the sources.

In Fig. 2, we present composition data versus estimated time since emission for the NEMR or EF for four major components present in the biomass burning smoke sampled for the FJ 9b fire: OA $\left(\mathrm{NEMR}_{\mathrm{OA}}\right.$; Fig. 2a), rBC (NEMR $\mathrm{rBC}$; Fig. 2b), $\mathrm{CO}\left(\mathrm{EF}_{\mathrm{CO}}\right.$; Fig. $\left.2 \mathrm{c}\right)$, and $\mathrm{CO}_{2}\left(\mathrm{EF}_{\mathrm{CO}_{2}}\right.$; Fig. $\left.2 \mathrm{~d}\right)$. Data near the source are presented as box-and-whisker plots (25th-75th and 10th-90th percentiles); these data were collected during roughly $2.5 \mathrm{~h}$ of sampling during which the modified combustion efficiency (MCE) (Ward and Radke, 1993) varied between 0.900 and 0.930 , which explains some of the variability in the data. Data up to $5 \mathrm{~h}$ downwind were obtained and are shown as open symbols. For downwind samples, vertical errors bars represent estimated measurement uncertainties, while horizontal error bars represent the range of estimated plume ages for non-perpendicular plume transects; horizontal error bars do not account for the estimated $30 \%$ measurement uncertainty in wind speed. To assess whether differences near the source and downwind are statistically significant, we conducted unpaired $t$ tests. When the corresponding two-tailed $p$ value $\leq 0.05$, we con- 


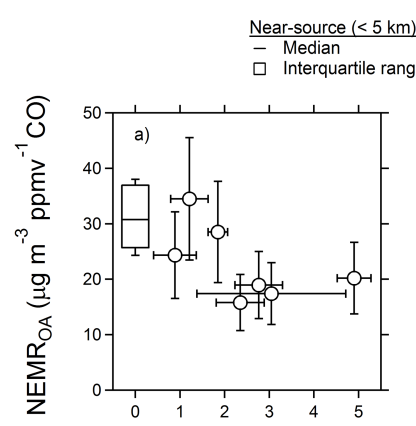

Est. time since emission $(h)$

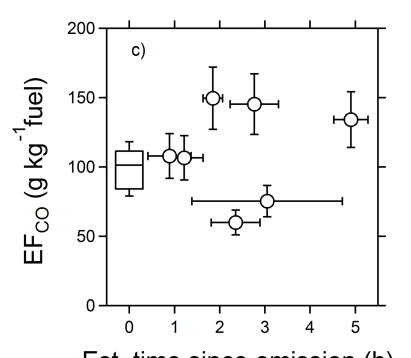

Est. time since emission (h)

$$
\frac{\text { Downwind }(>5 \mathrm{~km})}{0 \text { Data }}
$$

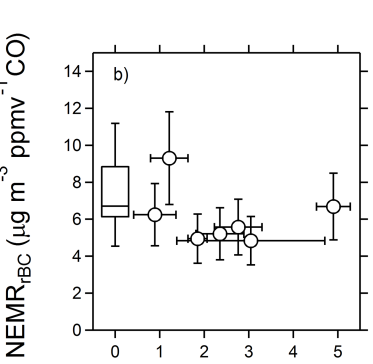

Est. time since emission (h)

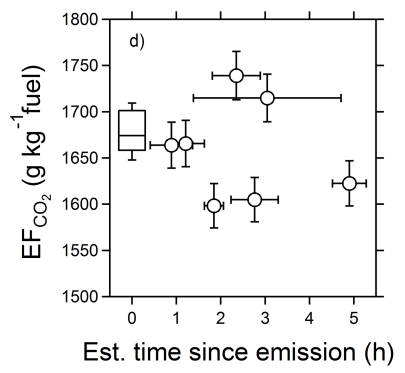

Figure 2. Near-source and downwind data collected during the FJ $9 \mathrm{~b}$ prescribed fire. (a) The ratio of excess $\mathrm{OA}$ to $\mathrm{CO}$; (b) the ratio of excess $\mathrm{rBC}$ to $\mathrm{CO} ; \mathbf{c})$ emission or export factor for $\mathrm{CO}$; and (d) emission or export factor of $\mathrm{CO}_{2}$. Near-source data are represented by box-and-whisker plots (boxes: 25th and 75th percentiles; whiskers: 10th and 90th percentiles; horizontal lines: median), while downwind data are represented by markers. Error bars associated with the markers indicate range of estimated time since emission ( $x$ direction) and measurement uncertainty ( $y$ direction). Error bars in $x$ direction do not account for estimated $30 \%$ accuracy of wind speed.

sider the results to be significantly different; conversely, if the $p$ value $>0.05$, we infer that there is no significant difference.

We expect $\mathrm{rBC}, \mathrm{CO}$, and $\mathrm{CO}_{2}$ to be conserved with transport since they are stable in the atmosphere on the timescales considered here. Indeed, unpaired $t$ tests for the data shown in Fig. 2b-d indicate that there was no significant difference in the average value of these species at the source and downwind (two-tailed $p$ values $>0.13$ ). Differences in mean downwind EFs are attributable to measurement uncertainties, including the identification of the plume edges, and variability in the combustion at the source. Fitting an exponential decay with distance from the source of the absolute mixing ratios of $\mathrm{CO}$ and $\mathrm{CO}_{2}$, we infer an average mixing rate (the inverse of the dilution timescale, or the time to decay by $1 / e$ ) of $1.6 \mathrm{~h}^{-1}$ during the FJ $9 \mathrm{~b}$ experiment.

Since OA is reactive and semi-volatile, it is perhaps not surprising that the downwind $\mathrm{NEMR}_{\mathrm{OA}}$ over $2-5 \mathrm{~h}$ of atmospheric aging is significantly lower than the $\mathrm{NEMR}_{\mathrm{OA}}$ at the source (Fig. 2a; two-tailed $p$ value $=0.015$ ), suggesting a net loss of emitted OA via evaporation and/or reaction. As
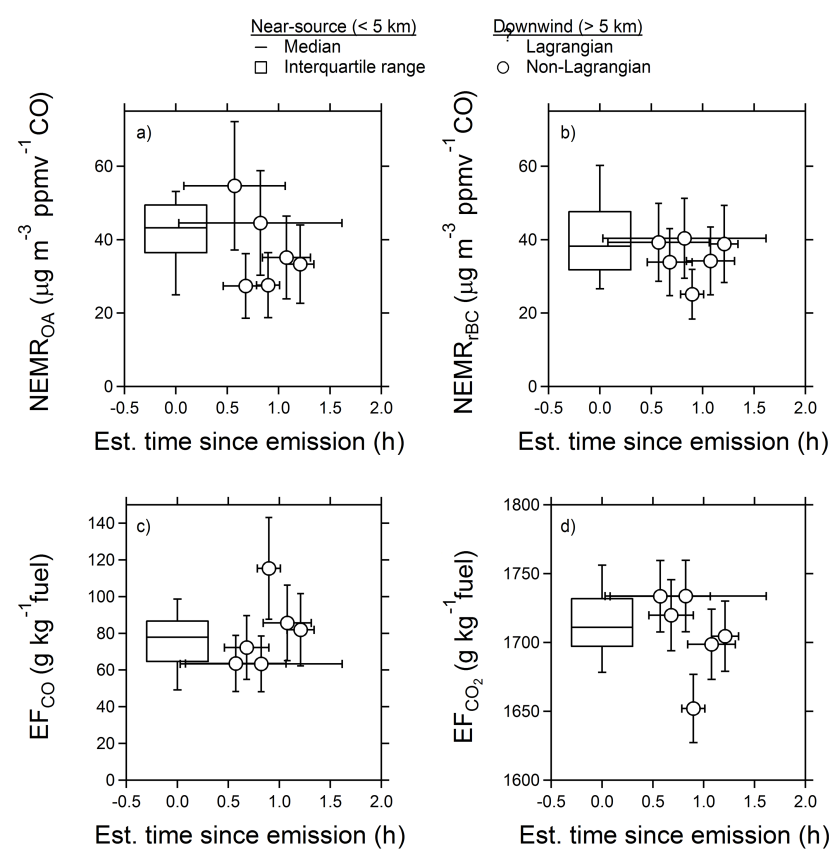

Figure 3. As in Fig. 2, but for the Francis Marion prescribed fire.

demonstrated by Akagi et al. (2013), the smoke plume was photochemically active, as is evident from enhancements of ozone and formaldehyde relative to the source.

Figure 3 is identical to Fig. 2 but represents the Francis Marion burn, the only other case with downwind aerosol measurements adequate to assess aging (here, up to $1.5 \mathrm{~h}$ after emission). Akagi et al. (2013) inferred that photochemical processing was occurring in the Francis Marion plume, based on observed downwind enhancements of ozone and formaldehyde relative to the source. However, unlike the FJ $9 \mathrm{~b}$ fire, none of the computed downwind NEMR and EF shown in Fig. 3 were significantly different from the source (all two-tailed $p$ values $>0.32$ ). The background OA concentrations, which we assume contribute to gas-particle partitioning of the OA emitted by the fire through the presence of additional absorptive material, were roughly $50 \%$ greater during the Francis Marion fire compared to the FJ 9b fire; furthermore, the mixing rate was $20 \%$ slower for the Francis Marion plume $\left(1.3 \mathrm{~h}^{-1}\right)$, and the plume aging was observed over a much shorter time period. These factors would slow the evaporation of emitted OA and limit the time over which chemical transformations could occur and be observed. Indeed, over the first $1.5 \mathrm{~h}$ after emission, the data for FJ $9 \mathrm{~b}$ shown in Fig. 2 also indicated no statistically significant change in NEMR $\mathrm{OA}$.

\subsection{Chemical transformations of organic aerosol}

In this section, we investigate chemical transformations of the organic aerosol using two approaches for both fires with adequate downwind data: the FJ $9 \mathrm{~b}$ and Francis Marion 


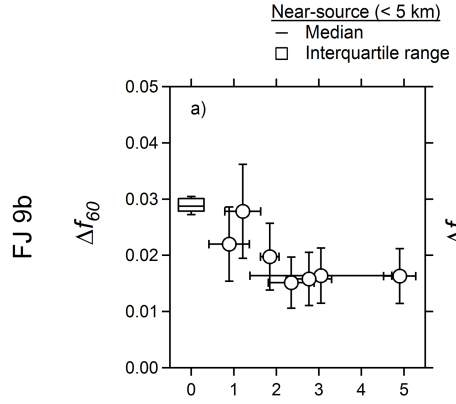

Est. time since emission (h)

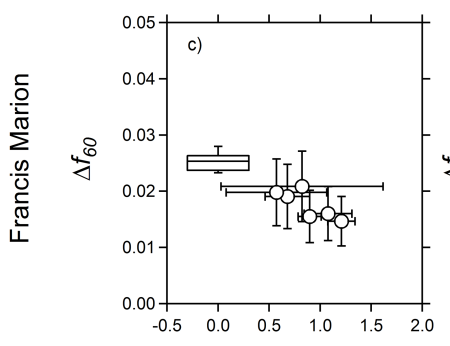

Est. time since emission (h)
Downwind $(>5 \mathrm{~km})$

O Data

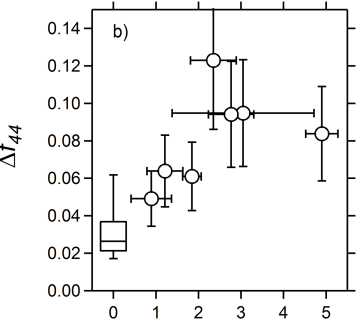

Est. time since emission (h)

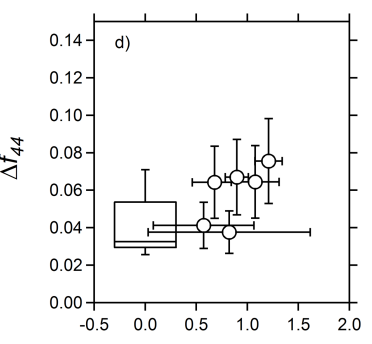

Est. time since emission (h)

Figure 4. Evolution of background-corrected AMS mass fractions. (a) $\Delta f_{60}$ for the FJ $9 \mathrm{~b}$ fire; (b) $\Delta f_{44}$ for the FJ $9 \mathrm{~b}$ fire; (c) $\Delta f_{60}$ for the Francis Marion fire; (d) $\Delta f_{44}$ for the Francis Marion fire. In all panels, there is a statistically significant difference between data collected near the source and downwind. Box-and-whisker plots and markers are used in the same way as those in Figs. 2 and 3.

burns. These include fragment evolution (Fig. 4) and elemental ratio analyses (Fig. 5).

Both Ng et al. (2010) and Morgan et al. (2010) demonstrated that "fresh" OA in ambient samples can be distinguished by organic fragment signatures in the mass spectra (e.g., $\mathrm{C}_{3} \mathrm{H}_{7}^{+}$at $m / z 43$ ), while "aged" $\mathrm{OA}$ is more highly oxidized and can be distinguished by a strong contribution of $\mathrm{CO}_{2}^{+}(\mathrm{m} / \mathrm{z} 44)$. The fractional contributions of each of these fragments to the total OA concentration (e.g., $f_{44}=C_{44} / C_{\mathrm{OA}}$, where $C_{44}$ is the mass concentration of particulate $\mathrm{CO}_{2}^{+}$, which is likely due to decarboxylation on the vaporizer surface rather than $\mathrm{CO}_{2}$ molecules being present in the aerosol sample) change with atmospheric aging: $f_{43}$ is expected to decrease and $f_{44}$ to increase.

However, neither Ng et al. (2010) nor Morgan et al. (2010) directly considered the influence of biomass burning. Cubison et al. (2011) and Ortega et al. (2013) modified the approach and compared $f_{60}$ and $f_{44}$ to infer the photochemical aging of biomass-burning-derived OA. Levoglucosan and other anhydrosugars are pyrolysis products of cellulose and thus are used as molecular markers for biomass burning emissions (Simoneit et al., 1999; Sullivan et al., 2008); these compounds contribute to AMS spectra at $m / z 60\left(\mathrm{C}_{2} \mathrm{H}_{4} \mathrm{O}_{2}^{+}\right)$ (Alfarra et al., 2007; Lee et al., 2010). May et al. (2012) and references therein demonstrated that levoglucosan is semivolatile at ambient conditions. Furthermore, Hennigan et
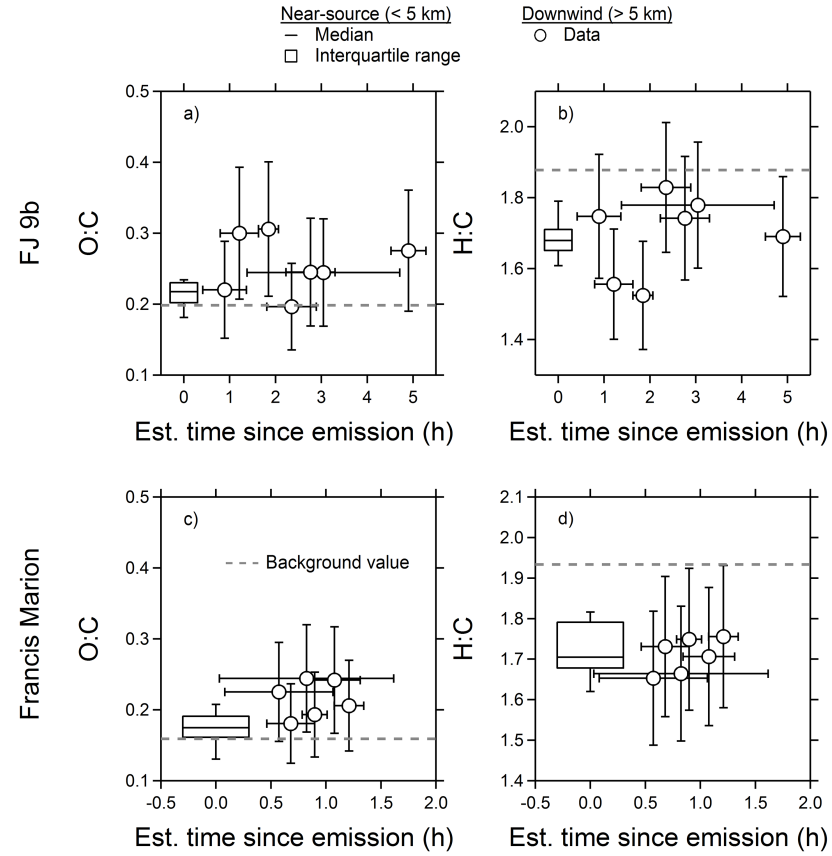

Figure 5. Evolution of elemental ratios derived from AMS data. (a) $\mathrm{O}: \mathrm{C}$ for the FJ $9 \mathrm{~b}$ fire; (b) $\mathrm{H}: \mathrm{C}$ for the FJ $9 \mathrm{~b}$ fire; (c) $\mathrm{O}: \mathrm{C}$ for the Francis Marion fire; (d) $\mathrm{H}: \mathrm{C}$ for the Francis Marion fire. For both fires, changes in $\mathrm{O}: \mathrm{C}$ with increasing estimated time since emission are statistically significant. Dashed line is the value of the parameter in the background measurements outside of plume penetrations. Box-and-whisker plots and markers are used in the same way as those in Figs. 2 and 3.

al. (2010) demonstrated that levoglucosan is reactive and chemically decays in a similar way to the hydrocarbonlike $(m / z 43)$ fragments. Thus, $f_{60}$ may change due to both dilution-driven evaporation and photooxidation processes if these findings for levoglucosan are extrapolated to all contributing species at $m / z 60$.

In Fig. 4, we present excess $f_{60}\left(\Delta f_{60}\right)$ and excess $f_{44}$ $\left(\Delta f_{44}\right)$ for the FJ $9 \mathrm{~b}$ and Francis Marion fires. These excess fragment fractional contributions were computed from background-corrected $\mathrm{m} / \mathrm{z} 60$ or $\mathrm{m} / \mathrm{z} 44$ mass concentrations by dividing those excess concentration by $\Delta \mathrm{OA}$. Thus, as the plume dilutes and becomes less distinguishable from the background, $\Delta f_{60}$ and $\Delta f_{44}$ should remain constant if neither preferentially evaporates, reacts, or accumulates within the plume. For the FJ $9 \mathrm{~b}$ fire, the source-downwind differences for both $\Delta f_{60}$ (Fig. 4a) and $\Delta f_{44}$ (Fig. 4b) are statistically significant (two-tailed $p$ value $<0.0001$ ). For the Francis Marion fire, $\Delta f_{60}$ (Fig. 4c) is significantly lower downwind than at the source (two-tailed $p$ value $<0.0001$ ), while $\Delta f_{44}$ (Fig. 4d) is significantly higher downwind than at the source (two-tailed $p$ value $=0.029$ ). The result for $\Delta f_{60}$ is consistent with Fig. 2a; that is, the decrease in $\Delta f_{60}$ downwind during the $\mathrm{FJ} 9 \mathrm{~b}$ fire reflects the decrease in NEMR $\mathrm{OA}_{\text {. }}$ An observed decrease in $\Delta f_{60}$ with no decrease in OA con- 
centration during the Francis Marion fire may be related to chemical reactions of compounds that fragment to $m / z 60$ or to differences in the volatility of these compounds compared to the bulk OA. The mechanistic driver of all transformations will be explored below.

The increase in $\Delta f_{44}$ with plume age for both fires indicates a compositional change toward increasing mass fractional contributions from molecules that fragment to $\mathrm{CO}_{2}^{+}$. If only dilution (and hence, evaporation) was occurring in the plumes as they moved downwind, $\Delta f_{44}$ should be conserved, provided its parent's volatility is similar to that of the bulk of the emitted OA. The observed increase in $\mathrm{CO}_{2}^{+}$in these photochemically active environments may indicate that production of SOA occurred within the plumes, although there were no statistically significant increases in the measured downwind NEMR $\mathrm{OA}$, as also found in some previous field studies (e.g., Capes et al., 2008; Cubison et al., 2011). On the other hand, this increase could also indicate that the species fragmenting to $m / z 44$ are relatively less volatile than the bulk $\mathrm{OA}$ that evaporates during transport and dilution.

Prior work investigating chemically resolved volatility has demonstrated that the evaporation of bulk OA can result in a relative increase in $m / z 44$ and a relative decrease in $m / z 60$. Huffman et al. (2009a) demonstrated for ambient samples in two different megacities that, at a given temperature in a thermodenuder, $m / z 60$ evaporated to a greater extent than the bulk OA, while $m / z 44$ evaporated to a lesser extent than the bulk OA. While heating OA is technically not the same as diluting $\mathrm{OA}$, the response of $\mathrm{OA}$ to increased temperature is analogous to the response of OA to increased dilution. Furthermore, Collier and Zhang (2013) demonstrated that $f_{44}$ increased with decreasing $C_{\mathrm{OA}}$ for vehicle test data in the absence of chemistry and hypothesized that this observation was attributable to preferential evaporation of less-oxidized OA species. Thus, the observed changes during SCREAM in $\Delta f_{44}$ and $\Delta f_{60}$ may be due, at least in part, to physical changes occurring as some of the emitted OA is volatilized upon dilution with ambient air.

A second framework for tracking the chemical evolution of OA was suggested by Heald et al. (2010), who proposed the use of elemental ratios (hydrogen to carbon, $\mathrm{H}: \mathrm{C}$, and oxygen to carbon, $\mathrm{O}: \mathrm{C}$ ) to describe the photochemical aging of OA. Similar to the fragment evolution, with increasing $\mathrm{OH}$ exposure, $\mathrm{H}: \mathrm{C}$ is expected to decrease (e.g., due to hydrogen abstraction reactions) and $\mathrm{O}: \mathrm{C}$ is expected to increase (e.g., due to oxygen addition to alkyl radicals). In Fig. 5 we present the evolution of the elemental ratios of $\mathrm{H}: \mathrm{C}$ and $\mathrm{O}: \mathrm{C}$ during atmospheric transport of the biomass burning plumes from both fires; values for the average background (i.e., out-of-plume) ratio for each fire are shown as dotted lines. We assume uncertainties of $31 \%$ for $\mathrm{O}: \mathrm{C}$ and $10 \%$ for $\mathrm{H}: \mathrm{C}$, based on Aiken et al. (2008).

For both fires, the average background $\mathrm{H}: \mathrm{C}$ ratio was roughly $15 \%$ greater than the $\mathrm{H}: \mathrm{C}$ at the source; downwind $\mathrm{H}: \mathrm{C}$ values were mostly within the source variability. As the plumes were transported downwind and mixed with background $\mathrm{OA}$, we expected $\mathrm{H}: \mathrm{C}$ to have increased toward the background values on a 2 to $3 \mathrm{~h}$ timescale (if it were a conserved tracer) based on measured dilution rates. The lack of a clear increase with time since emission in both experiments suggests either that loss of both $\mathrm{H}$ and $\mathrm{C}$ occurred in the plume or increases in $\mathrm{C}$ occurred without a corresponding addition of $\mathrm{H}$ that would maintain the $\mathrm{H}: \mathrm{C}$ observed at the source. Typically, $\mathrm{H}: \mathrm{C}$ decreases with increasing oxidation (Heald et al., 2010).

For $\mathrm{O}: \mathrm{C}$, about half the downwind values were higher than could be explained by measured variability at the source, and the background $\mathrm{OA}$ had $\mathrm{O}: \mathrm{C}$ within (but at the lower end of) the range at the source. Dilution with background air was thus expected to have had little impact on $\mathrm{O}: \mathrm{C}$ if $\mathrm{O}: \mathrm{C}$ were a conserved tracer. Like $m / z 44, \mathrm{O}: \mathrm{C}$ could have increased with time if photochemical production and condensation of high $\mathrm{O}: \mathrm{C}$ species or photochemical aging of aerosol had occurred (Kroll et al., 2011).

However, the observed decreases in $\mathrm{NEMR}_{\mathrm{OA}}$ (whether statistically significant or not) suggest that changes in $\mathrm{H}: \mathrm{C}$ and $\mathrm{O}: \mathrm{C}$ may potentially be induced by a solely physical process (i.e., if $\mathrm{C}$ were lost from the aerosol phase by preferential evaporation of species that had a lower $\mathrm{O}: \mathrm{C}$ than the average observed at the source). In fact, Huffman et al. (2009b) demonstrated that $\mathrm{O}: \mathrm{C}$ increased and $\mathrm{H}: \mathrm{C}$ decreased with increasing evaporation of bulk $\mathrm{OA}$ in biomass burning emissions during thermodenuder experiments. Hence, oxidative transformations may be difficult to differentiate from evaporative transformations.

\subsection{Physical transformations of organic aerosol}

A net loss of OA due solely to dilution-driven evaporation may thus be consistent with the observations in Figs. 2-5. However, we note that we cannot definitively state that no aerosol chemistry has occurred within the plumes as they age. In the following, we assume a priori knowledge that dilution-driven evaporation dominates over chemical processing and explore whether the volatility distribution derived by May et al. (2013) for laboratory biomass burning primary OA can reproduce our airborne observations. If it can, no oxidative chemistry is required to explain the data, although it is possible that some occurs.

Simulations representing the process of dilution alone are presented in Fig. 6, which shows $\mathrm{EF}_{\mathrm{OA}}$ data (representing the emission factors near the source and export factors downwind) as a function of the total mass concentration of observed organic aerosol (i.e., not background corrected), $C_{\mathrm{OA}}$, for six flights. Model curves were calculated using the following equation (Donahue et al., 2006; Robinson et al., 2010): 

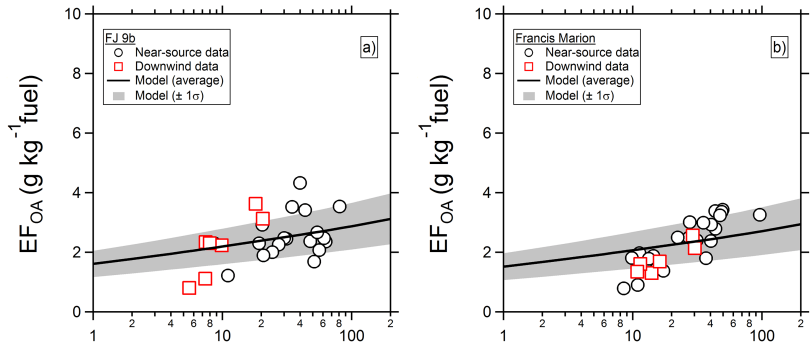

Intercept-averaged $\mathrm{C}_{\mathrm{OA}}\left(\mu \mathrm{g} \mathrm{m}^{-3}\right)$
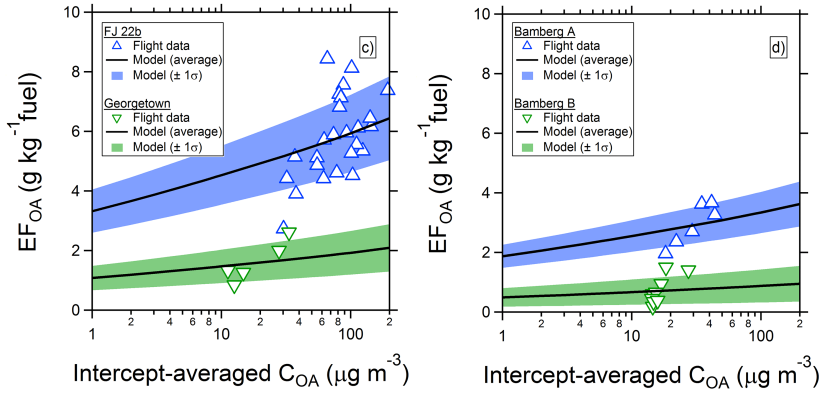

Figure 6. Changes in the emission factor of excess OA due to gasparticle partitioning as a function of total observed OA. (a) Nearsource (circles) and downwind (squares) data for the FJ 9b fire; (b) near-source (circles) and downwind (squares) data for the Francis Marion fire; (c) near-source data for the FJ 22b (upward-facing triangles) and Georgetown (downward-facing triangles) fires; and (d) near-source data for the two fires attributed to the Bamberg site ("A": upward-facing triangles; "B": downward-facing triangles). Curves represent predictions using the laboratory parameterization from May et al. (2013).

$\mathrm{EF}_{\mathrm{OA}}=\mathrm{EF}_{\mathrm{tot}} \sum_{i} f_{i}\left(1+\frac{C_{i}^{*}}{C_{\mathrm{OA}}}\right)^{-1}$

where $i$ represents arbitrarily chosen surrogate compounds defined by their saturation concentration $\left(C_{i}^{*}\right.$; related to saturation vapor pressure through the ideal gas law) and $f_{i}$ is the mass fraction of each species $i$ relative to the total emitted organics. The set of $f_{i}$ and $C_{i}^{*}$ is referred to as a volatility distribution. Here, we utilize the volatility distribution for emissions from open biomass burning that was proposed by May et al. (2013) and which is comprised of surrogate compounds representing seven logarithmically spaced $C_{i}^{*}$ bins. $C_{\mathrm{OA}}$ represents the total OA concentration (emissions + background).

$\mathrm{EF}_{\text {tot }}$ is the emission factor of total organics (gas + particle phase) that are constrained by the volatility distribution (here, all material between $C_{i}^{*}=3 \times 10^{-3}$ and $3 \times 10^{4} \mu \mathrm{g} \mathrm{m}^{-3}$, so this is not equivalent to NMOG) and hence contribute to gasparticle partitioning; $\mathrm{EF}_{\text {tot }}$ is likely dominated by biomassburning-derived organics but may include background semivolatile organic material that can partition into the particle phase due to the presence of the biomass burning smoke.
Values of $\mathrm{EF}_{\text {tot }}$ were inferred using Eq. (3) with measured $C_{\mathrm{OA}}$, calculated $\mathrm{EF}_{\mathrm{OA}}$ (from Eq. 2), and the volatility distribution from May et al. (2013) as inputs for each plume intercept. In Fig. 6, the lines represent predictions based on the average $\mathrm{EF}_{\text {tot }}$ inferred for each fire, while the shaded areas represent \pm 1 standard deviation in $\mathrm{EF}_{\text {tot }}$. Average values of $\mathrm{EF}_{\text {tot }}$ ranged from roughly $2 \mathrm{~g} \mathrm{~kg}^{-1}$ fuel (Bamberg $\mathrm{B}$ ) to $12 \mathrm{~g} \mathrm{~kg}^{-1}$ fuel (FJ 22b); both the FJ 9b and Francis Marion fires had inferred $\mathrm{EF}_{\text {tot }}$ values of roughly $6 \mathrm{~g} \mathrm{~kg}^{-1}$ fuel. Equation (3) implies that $\mathrm{EF}_{\mathrm{OA}}$ (regardless of whether this represents an emission factor or export factor) decreases with increasing dilution, due to the physical repartitioning of semivolatile species.

There are some key assumptions in our use of Eq. (3). We assume that the gas-particle partitioning of the OA can be described using a parameterization derived for laboratory fires, even though the OA in our samples has originated from prescribed fires in the field and may be enhanced by background semi-volatile organics. We are also assuming that $\mathrm{EF}_{\text {tot }}$ is constant in time for a given prescribed fire (i.e., it does not vary due to source variability, mixing with background air, or atmospheric chemistry). Finally, we are inherently assuming that the plume temperature is constant at $298 \mathrm{~K}$, so dilution is the only process affecting gas-particle partitioning. While these assumptions are not strictly true, they should not affect our conclusions significantly on average.

Figure $6 \mathrm{a}$ and $\mathrm{b}$ provide $\mathrm{EF}_{\mathrm{OA}}$ calculated near the source and downwind for the FJ $9 \mathrm{~b}$ and Francis Marion fires, respectively. Near-source data from the FJ 22b and Georgetown fires are presented in Fig. $6 \mathrm{c}$ and from the Bamberg fires in Fig. 6d. Generally, the near-source data for all fires follow the expected trend, exhibiting a decrease in $\mathrm{EF}_{\mathrm{OA}}$ with decreasing total measured (i.e., not background-corrected) $C_{\mathrm{OA}}$, as would be expected for a semi-volatile tracer with the characteristics summarized by May et al. (2013); variability in near-source data arises due to proximity to the source and to the center of the plume as well as the smoke production rate. Downwind data (only available for Fig. 6a and b) also generally follow the trend predicted by Eq. (3), suggesting that the evaporation of emitted OA dominates over any production and condensation of SOA. Performing a $t$ test on the inferred $\mathrm{EF}_{\text {tot }}$ for both the FJ $9 \mathrm{~b}$ and Francis Marion fires indicates that the differences between near-source and downwind values are not statistically significant ( $p$ value $>0.1$ ), suggesting no observable SOA production from oxidation reactions (e.g., excess $\mathrm{OA}$ has reached equilibrium).

We must note that the predictions in Fig. 6 are based on a composite volatility distribution that best represented biomass fuels investigated in the laboratory during the FLAME-III study, which has been extrapolated to the field in this study. Also, fire behavior was variable during the several hours over which data were collected, as evident in the ground-based MCE measurements (Akagi et al., 2014); the emissions of organics has been demonstrated to vary with MCE (May et al., 2014; McMeeking et al., 2009). All data 
are represented using a single set of model inputs, which does not account for this variability with MCE. While other factors probably play a role, these two are likely to be the most important. Regardless, the differences in OA observed at the source and downwind for these plumes can be explained by a simple model of gas-particle partitioning.

\section{Conclusions}

In this work, we present field observations of the physicochemical evolution of the organic aerosol present in biomass burning plumes from two prescribed fires in South Carolina. Downwind observations of $\mathrm{rBC}$ to $\mathrm{CO}$ ratios, emission factors of $\mathrm{CO}$, and $\mathrm{CO}_{2}$ are not statistically different on average from those at the source. The downwind ratio of $\mathrm{OA}$ to $\mathrm{CO}$ was significantly lower than at the source for the fire that we were able to follow downwind for up to $5 \mathrm{~h}$ of atmospheric aging. The downwind $\mathrm{OA}$ to $\mathrm{CO}$ ratio was not significantly different downwind for the other fire, which may be related to the much shorter observable atmospheric aging time $(\sim 2 \mathrm{~h})$.

We observed significant differences in downwind ratios of AMS mass fragments thought to be indicative of fresh biomass burning emissions $(\mathrm{m} / \mathrm{z} 60$, which decreased) and more oxidized OA species ( $m / z 44$, which increased), consistent with prior reported laboratory photooxidation experiments. While the observed increases in $\Delta f_{44}$ (and the $\mathrm{O}: \mathrm{C}$ ratio) imply the possibility of SOA production within the plume, these observed changes are also consistent with differences in the volatilities of the species fragmenting to $m / z 60$ and $m / z 44$ relative to the bulk OA, resulting in differences in evaporation as the plume dilutes into background air.

Our observations and model simulations suggest that dilution-driven evaporation out of the particle phase dominated over the condensation of semi-volatile material into the particle phase over roughly the first $2 \mathrm{~h}$ of transport during the FJ $9 \mathrm{~b}$ fire. After this, the OA in the plume reached an apparent steady state with the background in our observations, as there is no net change to $\mathrm{NEMR}_{\mathrm{OA}}$ (i.e., there is no obvious dilution-driven evaporation or SOA production); thus, OA transformation can be predicted with a simple gasparticle partitioning model. For the Francis Marion fire, due to limited downwind data, we cannot draw a similar conclusion with any certainty. The decrease in $\mathrm{NEMR}_{\mathrm{OA}}$ for the FJ $9 \mathrm{~b}$ fire is consistent with results from previous literature (Akagi et al., 2012; Jolleys et al., 2012, 2015); however, other studies report increases in OA with increasing plume age (DeCarlo et al., 2008; Vakkari et al., 2014; Yokelson et al., 2009). The exact cause of this variability in observations is unclear. These remaining unexplained differences among different field studies highlight the need for additional research on atmospheric physicochemical transformations of biomass burning plumes.
Acknowledgements. We acknowledge funding from the Joint Fire Science Program under project JFSP 11-1-5-12 to S. M. Kreidenweis and from the Strategic Environmental Research and Development Program project RC-1649 administered partly through the Forest Service Research Joint Venture Agreement 08JV11272166039 to R. J. Yokelson. Additional flight hours and CRDS data were provided by Joint Fire Science Program project 08-1-6-09 to S. Urbanski. The adaptation of the Twin Otter was supported by NSF grants ATM-0531044 and ATM-0936321 to R. J. Yokelson. We also thank Ezra Levin and the NSF/NCAR Research Aviation Facility for assistance with the installation of instruments on the Twin Otter; Shane Murphy, Roya Bahreini, and Ann Middlebrook for guidance in modifying the CSU AMS for aircraft operation; and Jose Jimenez, Tim Onasch, Jill Craven, and Misha Schurman for discussions related to AMS data analysis. This work would not have been possible without the support of the Twin Otter Support Team, especially pilot Bill Mank and mechanic Steve Woods; John Maitland and the forestry staff at Fort Jackson who conducted those prescribed fires; and the Columbia Dispatch Office of the South Carolina Forestry Commission who provided additional prescribed fire locations during the campaign.

Edited by: J. Allan

\section{References}

Aiken, A. C., Decarlo, P. F., Kroll, J. H., Worsnop, D. R., Huffman, J. A., Docherty, K. S., Ulbrich, I. M., Mohr, C., Kimmel, J. R., Sueper, D., Sun, Y., Zhang, Q., Trimborn, A., Northway, M., Ziemann, P. J., Canagaratna, M. R., Onasch, T. B., Alfarra, M. R., Prevot, A. S. H., Dommen, J., Duplissy, J., Metzger, A., Baltensperger, U., and Jimenez, J. L.: O / C and OM / OC Ratios of Primary, Secondary, and Ambient Organic Aerosols with HighResolution Time-of-Flight Aerosol Mass Spectrometry, Environ. Sci. Technol., 42, 4478-4485, doi:10.1021/es703009q, 2008.

Akagi, S. K., Yokelson, R. J., Wiedinmyer, C., Alvarado, M. J., Reid, J. S., Karl, T., Crounse, J. D., and Wennberg, P. O.: Emission factors for open and domestic biomass burning for use in atmospheric models, Atmos. Chem. Phys., 11, 4039-4072, doi:10.5194/acp-11-4039-2011, 2011.

Akagi, S. K., Craven, J. S., Taylor, J. W., McMeeking, G. R., Yokelson, R. J., Burling, I. R., Urbanski, S. P., Wold, C. E., Seinfeld, J. H., Coe, H., Alvarado, M. J., and Weise, D. R.: Evolution of trace gases and particles emitted by a chaparral fire in California, Atmos. Chem. Phys., 12, 1397-1421, doi:10.5194/acp-12-13972012, 2012.

Akagi, S. K., Yokelson, R. J., Burling, I. R., Meinardi, S., Simpson, I., Blake, D. R., McMeeking, G. R., Sullivan, A., Lee, T., Kreidenweis, S., Urbanski, S., Reardon, J., Griffith, D. W. T., Johnson, T. J., and Weise, D. R.: Measurements of reactive trace gases and variable $\mathrm{O}_{3}$ formation rates in some South Carolina biomass burning plumes, Atmos. Chem. Phys., 13, 1141-1165, doi:10.5194/acp-13-1141-2013, 2013.

Akagi, S. K., Burling, I. R., Mendoza, A., Johnson, T. J., Cameron, M., Griffith, D. W. T., Paton-Walsh, C., Weise, D. R., Reardon, J., and Yokelson, R. J.: Field measurements of trace gases emitted by prescribed fires in southeastern US pine forests using 
an open-path FTIR system, Atmos. Chem. Phys., 14, 199-215, doi:10.5194/acp-14-199-2014, 2014.

Alfarra, M. R., Prévôt, A. S. H., Szidat, S., Sandradewi, J., Weimer, S., Lanz, V. A., Schreiber, D., Mohr, M., and Baltensperger, U.: Identification of the Mass Spectral Signature of Organic Aerosols from Wood Burning Emissions, Environ. Sci. Technol., 41, 5770-5777, doi:10.1021/es062289b, 2007

Allan, J. D., Delia, A. E., Coe, H., Bower, K. N., Alfarra, M. R., Jimenez, J. L., Middlebrook, A. M., Drewnick, F., Onasch, T. B., Canagaratna, M. R., Jayne, J. T., and Worsnop, D. R.: A generalised method for the extraction of chemically resolved mass spectra from Aerodyne aerosol mass spectrometer data, J. Aerosol Sci., 35, 909-922, doi:10.1016/j.jaerosci.2004.02.007, 2004.

Andreae, M. O. and Gelencsér, A.: Black carbon or brown carbon? The nature of light-absorbing carbonaceous aerosols, Atmos. Chem. Phys., 6, 3131-3148, doi:10.5194/acp-6-3131-2006, 2006.

Andreae, M. O. and Merlet, P.: Emission of trace gases and aerosols from biomass burning, Global Biogeochem. Cy., 15, 955-966, doi:10.1029/2000GB001382, 2001.

Bahreini, R., Dunlea, E. J., Matthew, B. M., Simons, C., Docherty, K. S., DeCarlo, P. F., Jimenez, J. L., Brock, C. A., and Middlebrook, A. M.: Design and Operation of a PressureControlled Inlet for Airborne Sampling with an Aerodynamic Aerosol Lens, Aerosol Sci. Technol., 42, 465-471, doi:10.1080/02786820802178514, 2008.

Bond, T. C., Doherty, S. J., Fahey, D. W., Forster, P. M., Berntsen, T., DeAngelo, B. J., Flanner, M. G., Ghan, S., Kärcher, B., Koch, D., Kinne, S., Kondo, Y., Quinn, P. K., Sarofim, M. C., Schultz, M. G., Schulz, M., Venkataraman, C., Zhang, H., Zhang, S., Bellouin, N., Guttikunda, S. K., Hopke, P. K., Jacobson, M. Z., Kaiser, J. W., Klimont, Z., Lohmann, U., Schwarz, J. P., Shindell, D., Storelvmo, T., Warren, S. G., and Zender, C. S.: Bounding the role of black carbon in the climate system: A scientific assessment, J. Geophys. Res. Atmos., 118, 5380-5552, doi:10.1002/jgrd.50171, 2013.

Burling, I. R., Yokelson, R. J., Griffith, D. W. T., Johnson, T. J., Veres, P., Roberts, J. M., Warneke, C., Urbanski, S. P., Reardon, J., Weise, D. R., Hao, W. M., and de Gouw, J.: Laboratory measurements of trace gas emissions from biomass burning of fuel types from the southeastern and southwestern United States, Atmos. Chem. Phys., 10, 11115-11130, doi:10.5194/acp10-11115-2010, 2010.

Burling, I. R., Yokelson, R. J., Akagi, S. K., Urbanski, S. P., Wold, C. E., Griffith, D. W. T., Johnson, T. J., Reardon, J., and Weise, D. R.: Airborne and ground-based measurements of the trace gases and particles emitted by prescribed fires in the United States, Atmos. Chem. Phys., 11, 12197-12216, doi:10.5194/acp11-12197-2011, 2011.

Capes, G., Johnson, B., McFiggans, G., Williams, P. I., Haywood, J., and Coe, H.: Aging of biomass burning aerosols over West Africa: Aircraft measurements of chemical composition, microphysical properties, and emission ratios, J. Geophys. Res., 113, D00C15, doi:10.1029/2008JD009845, 2008.

Christian, T. J., Kleiss, B., Yokelson, R. J., Holzinger, R., Crutzen, P. J., Hao, W. M., Saharjo, B. H., and Ward, D. E.: Comprehensive laboratory measurements of biomass-burning emissions: 1 .
Emissions from Indonesian, African, and other fuels, J. Geophys. Res., 108, 4719, doi:10.1029/2003JD003704, 2003.

Collier, S. and Zhang, Q.: Gas-phase $\mathrm{CO}_{2}$ subtraction for improved measurements of the organic aerosol mass concentration and oxidation degree by an aerosol mass spectrometer, Environ. Sci. Technol., 47, 14324-14331, doi:10.1021/es404024h, 2013.

Cubison, M. J., Ortega, A. M., Hayes, P. L., Farmer, D. K., Day, D., Lechner, M. J., Brune, W. H., Apel, E., Diskin, G. S., Fisher, J. A., Fuelberg, H. E., Hecobian, A., Knapp, D. J., Mikoviny, T., Riemer, D., Sachse, G. W., Sessions, W., Weber, R. J., Weinheimer, A. J., Wisthaler, A., and Jimenez, J. L.: Effects of aging on organic aerosol from open biomass burning smoke in aircraft and laboratory studies, Atmos. Chem. Phys., 11, 12049-12064, doi:10.5194/acp-11-12049-2011, 2011.

DeCarlo, P. F., Kimmel, J. R., Trimborn, A., Northway, M. J., Jayne, J. T., Aiken, A. C., Gonin, M., Fuhrer, K., Horvath, T., Docherty, K. S., Worsnop, D. R., and Jimenez, J. L.: Field-deployable, high-resolution, time-of-flight aerosol mass spectrometer, Anal. Chem., 78, 8281-8289, doi:10.1021/ac061249n, 2006.

DeCarlo, P. F., Dunlea, E. J., Kimmel, J. R., Aiken, A. C., Sueper, D., Crounse, J., Wennberg, P. O., Emmons, L., Shinozuka, Y., Clarke, A., Zhou, J., Tomlinson, J., Collins, D. R., Knapp, D., Weinheimer, A. J., Montzka, D. D., Campos, T., and Jimenez, J. L.: Fast airborne aerosol size and chemistry measurements above Mexico City and Central Mexico during the MILAGRO campaign, Atmos. Chem. Phys., 8, 4027-4048, doi:10.5194/acp-84027-2008, 2008.

Donahue, N. M., Chuang, W., Epstein, S. A., Kroll, J. H., Worsnop, D. R., Robinson, A. L., Adams, P. J., and Pandis, S. N.: Why do organic aerosols exist? Understanding aerosol lifetimes using the two-dimensional volatility basis set, Environ. Chem., 10, 151157, doi:10.1071/EN13022, 2013.

Heald, C. L., Kroll, J. H., Jimenez, J. L., Docherty, K. S., DeCarlo, P. F., Aiken, A. C., Chen, Q., Martin, S. T., Farmer, D. K., and Artaxo, P.: A simplified description of the evolution of organic aerosol composition in the atmosphere, Geophys. Res. Lett., 37, L08803, doi:10.1029/2010GL042737, 2010.

Heilman, W. E., Liu, Y., Urbanski, S., Kovalev, V., and Mickler, R.: Wildland fire emissions, carbon, and climate: Plume rise, atmospheric transport, and chemistry processes, Forest Ecol. Manag., 317, 70-79, doi:10.1016/j.foreco.2013.02.001, 2014.

Hennigan, C. J., Sullivan, A. P., Collett, J. L., and Robinson, A. L.: Levoglucosan stability in biomass burning particles exposed to hydroxyl radicals, Geophys. Res. Lett., 37, L09806, doi:10.1029/2010GL043088, 2010.

Hennigan, C. J., Miracolo, M. A., Engelhart, G. J., May, A. A., Presto, A. A., Lee, T., Sullivan, A. P., McMeeking, G. R., Coe, H., Wold, C. E., Hao, W.-M., Gilman, J. B., Kuster, W. C., de Gouw, J., Schichtel, B. A., Collett Jr., J. L., Kreidenweis, S. M., and Robinson, A. L.: Chemical and physical transformations of organic aerosol from the photo-oxidation of open biomass burning emissions in an environmental chamber, Atmos. Chem. Phys., 11, 7669-7686, doi:10.5194/acp-11-7669-2011, 2011.

Hobbs, P. V., Sinha, P., Yokelson, R. J., Christian, T. J., Blake, D. R., Gao, S., Kirchstetter, T. W., Novakov, T., and Pilewskie, P.: Evolution of gases and particles from a savanna fire in South Africa, J. Geophys. Res., 108, 8485, doi:10.1029/2002JD002352, 2003.

Hosseini, S., Urbanski, S. P., Dixit, P., Qi, L., Burling, I. R., Yokelson, R. J., Johnson, T. J., Shrivastava, M., Jung, H. S., 
Weise, D. R., Miller, J. W., and Cocker, D. R.: Laboratory characterization of PM emissions from combustion of wildland biomass fuels, J. Geophys. Res.-Atmos., 118, 9914-9929, doi:10.1002/jgrd.50481, 2013.

Huffman, J. A., Docherty, K. S., Aiken, A. C., Cubison, M. J., Ulbrich, I. M., DeCarlo, P. F., Sueper, D., Jayne, J. T., Worsnop, D. R., Ziemann, P. J., and Jimenez, J. L.: Chemically-resolved aerosol volatility measurements from two megacity field studies, Atmos. Chem. Phys., 9, 7161-7182, doi:10.5194/acp-9-71612009, 2009a.

Huffman, J. A., Docherty, K. S., Mohr, C., Cubison, M. J., U1brich, I. M., Ziemann, P. J., Onasch, T. B., and Jimenez, J. L.: Chemically-Resolved Volatility Measurements of Organic Aerosol from Different Sources, Environ. Sci. Technol., 43, 5351-5357, doi:10.1021/es803539d, 2009b.

Jolleys, M. D., Coe, H., McFiggans, G., Capes, G., Allan, J. D., Crosier, J., Williams, P. I., Allen, G., Bower, K. N., Jimenez, J. L., Russell, L. M., Grutter, M., and Baumgardner, D.: Characterizing the aging of biomass burning organic aerosol by use of mixing ratios: a meta-analysis of four regions, Environ. Sci. Technol., 46, 13093-13102, doi:10.1021/es302386v, 2012.

Jolleys, M. D., Coe, H., McFiggans, G., McMeeking, G. R., Lee, T., Kreidenweis, S. M., Collett, J. L., and Sullivan, A. P.: Organic aerosol emission ratios from the laboratory combustion of biomass fuels, J. Geophys. Res. Atmos., 119, 12850-12871, doi:10.1002/2014JD021589, 2014.

Jolleys, M. D., Coe, H., McFiggans, G., Taylor, J. W., O'Shea, S. J., Le Breton, M., Bauguitte, S. J.-B., Moller, S., Di Carlo, P., Aruffo, E., Palmer, P. I., Lee, J. D., Percival, C. J., and Gallagher, M. W.: Properties and evolution of biomass burning organic aerosol from Canadian boreal forest fires, Atmos. Chem. Phys., 15, 3077-3095, doi:10.5194/acp-15-3077-2015, 2015.

Kirchstetter, T. W., Novakov, T., and Hobbs, P. V.: Evidence that the spectral dependence of light absorption by aerosols is affected by organic carbon, J. Geophys. Res., 109, D21208, doi:10.1029/2004JD004999, 2004.

Kroll, J. H., Donahue, N. M., Jimenez, J. L., Kessler, S. H., Canagaratna, M. R., Wilson, K. R., Altieri, K. E., Mazzoleni, L. R., Wozniak, A. S., Bluhm, H., Mysak, E. R., Smith, J. D., Kolb, C. E., and Worsnop, D. R.: Carbon oxidation state as a metric for describing the chemistry of atmospheric organic aerosol, Nat. Chem., 3, 133-139, doi:10.1038/nchem.948, 2011.

Lack, D. A., Langridge, J. M., Bahreini, R., Cappa, C. D., Middlebrook, A. M., and Schwarz, J. P.: Brown carbon and internal mixing in biomass burning particles, P. Natl. Acad. Sci. USA, 109, 14802-14807, doi:10.1073/pnas.1206575109, 2012.

Lee, T., Sullivan, A. P., Mack, L., Jimenez, J. L., Kreidenweis, S. M., Onasch, T. B., Worsnop, D. R., Malm, W., Wold, C. E., Hao, W. M., and Collett, J. L.: Chemical Smoke Marker Emissions During Flaming and Smoldering Phases of Laboratory Open Burning of Wildland Fuels, Aerosol Sci. Technol., 44, i-v, doi:10.1080/02786826.2010.499884, 2010.

Marple, V. A., Rubow, K. L., and Behm, S. M.: A Microorifice Uniform Deposit Impactor (MOUDI): Description, Calibration, and Use, Aerosol Sci. Technol., 14, 434-446, doi:10.1080/02786829108959504, 1991.

May, A. A., Saleh, R., Hennigan, C. J., Donahue, N. M., and Robinson, A. L.: Volatility of organic molecular markers used for source apportionment analysis: measurements and implications for atmospheric lifetime, Environ. Sci. Technol., 46, 12435-44, doi:10.1021/es302276t, 2012.

May, A. A., Levin, E. J. T., Hennigan, C. J., Riipinen, I., Lee, T., Collett, J. L., Jimenez, J. L., Kreidenweis, S. M., and Robinson, A. L.: Gas-particle partitioning of primary organic aerosol emissions: 3. Biomass burning, J. Geophys. Res. Atmos., 118, 1132711338, doi:10.1002/jgrd.50828, 2013.

May, A. A., McMeeking, G. R., Lee, T., Taylor, J. W., Craven, J. S., Burling, I., Sullivan, A. P., Akagi, S., Collett, J. L., Flynn, M., Coe, H., Urbanski, S. P., Seinfeld, J. H., Yokelson, R. J., and Kreidenweis, S. M.: Aerosol emissions from prescribed fires in the United States: A synthesis of laboratory and aircraft measurements, J. Geophys. Res.-Atmos., 119, 11826-11849, doi:10.1002/2014JD021848, 2014.

McMeeking, G. R., Kreidenweis, S. M., Baker, S., Carrico, C. M., Chow, J. C., Collett, J. L., Hao, W. M., Holden, A. S., Kirchstetter, T. W., Malm, W. C., Moosmüller, H., Sullivan, A. P., and Wold, C. E.: Emissions of trace gases and aerosols during the open combustion of biomass in the laboratory, J. Geophys. Res., 114, D19210, doi:10.1029/2009JD011836, 2009.

Middlebrook, A. M., Bahreini, R., Jimenez, J. L., and Canagaratna, M. R.: Evaluation of Composition-Dependent Collection Efficiencies for the Aerodyne Aerosol Mass Spectrometer using Field Data, Aerosol Sci. Technol., 46, 258-271, doi:10.1080/02786826.2011.620041, 2012.

Morgan, W. T., Allan, J. D., Bower, K. N., Highwood, E. J., Liu, D., McMeeking, G. R., Northway, M. J., Williams, P. I., Krejci, R., and Coe, H.: Airborne measurements of the spatial distribution of aerosol chemical composition across Europe and evolution of the organic fraction, Atmos. Chem. Phys., 10, 4065-4083, doi:10.5194/acp-10-4065-2010, 2010.

Ng, N. L., Canagaratna, M. R., Zhang, Q., Jimenez, J. L., Tian, J., Ulbrich, I. M., Kroll, J. H., Docherty, K. S., Chhabra, P. S., Bahreini, R., Murphy, S. M., Seinfeld, J. H., Hildebrandt, L., Donahue, N. M., DeCarlo, P. F., Lanz, V. A., Prévôt, A. S. H., Dinar, E., Rudich, Y., and Worsnop, D. R.: Organic aerosol components observed in Northern Hemispheric datasets from Aerosol Mass Spectrometry, Atmos. Chem. Phys., 10, 46254641, doi:10.5194/acp-10-4625-2010, 2010.

Ortega, A. M., Day, D. A., Cubison, M. J., Brune, W. H., Bon, D., de Gouw, J. A., and Jimenez, J. L.: Secondary organic aerosol formation and primary organic aerosol oxidation from biomass-burning smoke in a flow reactor during FLAME-3, Atmos. Chem. Phys., 13, 11551-11571, doi:10.5194/acp-1311551-2013, 2013.

Reid, J. S., Koppmann, R., Eck, T. F., and Eleuterio, D. P.: A review of biomass burning emissions part II: intensive physical properties of biomass burning particles, Atmos. Chem. Phys., 5, 799825, doi:10.5194/acp-5-799-2005, 2005.

Robinson, A. L., Grieshop, A. P., Donahue, N. M., and Hunt, S. W.: Updating the Conceptual Model for Fine Particle Mass Emissions from Combustion Systems, J. Air Waste Manage., 60, 1204-1222, doi:10.3155/1047-3289.60.10.1204, 2010.

Schwarz, J. P., Gao, R. S., Fahey, D. W., Thomson, D. S., Watts, L. A., Wilson, J. C., Reeves, J. M., Darbeheshti, M., Baumgardner, D. G., Kok, G. L., Chung, S. H., Schulz, M., Hendricks, J., Lauer, A., Kärcher, B., Slowik, J. G., Rosenlof, K. H., Thompson, T. L., Langford, A. O., Loewenstein, M., and Aikin, K. C.: Single-particle measurements of midlatitude black 
carbon and light-scattering aerosols from the boundary layer to the lower stratosphere, J. Geophys. Res. Atmos., 111, D16207, doi:10.1029/2006JD007076, 2006.

Simoneit, B. R. T., Schauer, J. J., Nolte, C. G., Oros, D. R., Elias, V. O., Fraser, M. P., Rogge, W. F., and Cass, G. R.: Levoglucosan, a tracer for cellulose in biomass burning and atmospheric particles, Atmos. Environ., 33, 173-182, doi:10.1016/S13522310(98)00145-9, 1999.

Stephens, M., Turner, N., and Sandberg, J.: Particle Identification by Laser-Induced Incandescence in a Solid-State Laser Cavity, Appl. Optics, 42, 3726, doi:10.1364/AO.42.003726, 2003.

Sueper, D., DeCarlo, P. F., Aiken, A. C., and Jimenez, J. L.: ToF-AMS High Resolution Analysis Software, available at: http://cires.colorado.edu/jimenez-group/wiki/index.php/ ToF-AMS_Analysis_Software (last access: 2 June 2015), 2013.

Sullivan, A. P., Holden, A. S., Patterson, L. A., McMeeking, G. R., Kreidenweis, S. M., Malm, W. C., Hao, W. M., Wold, C. E., and Collett, J. L.: A method for smoke marker measurements and its potential application for determining the contribution of biomass burning from wildfires and prescribed fires to ambient $\mathrm{PM}_{2.5}$ organic carbon, J. Geophys. Res., 113, D22302, doi:10.1029/2008JD010216, 2008.

Sullivan, A. P., May, A. A., Lee, T., McMeeking, G. R., Kreidenweis, S. M., Akagi, S. K., Yokelson, R. J., Urbanski, S. P., and Collett Jr., J. L.: Airborne characterization of smoke marker ratios from prescribed burning, Atmos. Chem. Phys., 14, 1053510545, doi:10.5194/acp-14-10535-2014, 2014.

Urbanski, S. P.: Combustion efficiency and emission factors for wildfire-season fires in mixed conifer forests of the northern Rocky Mountains, US, Atmos. Chem. Phys., 13, 7241-7262, doi:10.5194/acp-13-7241-2013, 2013.

Urbanski, S. P., Hao, W. M., and Nordgren, B.: The wildland fire emission inventory: western United States emission estimates and an evaluation of uncertainty, Atmos. Chem. Phys., 11, 12973-13000, doi:10.5194/acp-11-12973-2011, 2011.

Vakkari, V., Kerminen, V.-M., Beukes, J. P., Tiitta, P., van Zyl, P. G., Josipovic, M., Venter, A. D., Jaars, K., Worsnop, D. R., Kulmala, M., and Laakso, L.: Rapid changes in biomass burning aerosols by atmospheric oxidation, Geophys. Res. Lett., 41, 2644-2651, doi:10.1002/2014GL059396, 2014.

van der Werf, G. R., Randerson, J. T., Giglio, L., Collatz, G. J., Mu, M., Kasibhatla, P. S., Morton, D. C., DeFries, R. S., Jin, Y., and van Leeuwen, T. T.: Global fire emissions and the contribution of deforestation, savanna, forest, agricultural, and peat fires (19972009), Atmos. Chem. Phys., 10, 11707-11735, doi:10.5194/acp10-11707-2010, 2010.
Ward, D. E. and Radke, L. F.: Emissions measurements from vegetation fires: A comparative evaluation of methods and results, in: Fire in the Environment: The Ecological, Atmospheric, and Climatic Importance of Vegetation Fires, edited by: Crutzen, P. J. and Goldammer, J. G., 53-76, John Wiley \& Sons, Inc., Chischester, England., 1993.

Watson, J. G., Chow, J. C., Chen, L.-W. A., Lowenthal, D. H., Fujita, E. M., Kuhns, H. D., Sodeman, D. A., Campbell, D. E., Moosmüller, H., Zhu, D., and Motallebi, N.: Particulate emission factors for mobile fossil fuel and biomass combustion sources, Sci. Total Environ., 409, 2384-2396, doi:10.1016/j.scitotenv.2011.02.041, 2011.

Wiedinmyer, C., Quayle, B., Geron, C., Belote, A., McKenzie, D., Zhang, X., O'Neill, S., and Wynne, K. K.: Estimating emissions from fires in North America for air quality modeling, Atmos. Environ., 40, 3419-3432, doi:10.1016/j.atmosenv.2006.02.010, 2006.

Wiedinmyer, C., Akagi, S. K., Yokelson, R. J., Emmons, L. K., AlSaadi, J. A., Orlando, J. J., and Soja, A. J.: The Fire INventory from NCAR (FINN): a high resolution global model to estimate the emissions from open burning, Geosci. Model Dev., 4, 625641, doi:10.5194/gmd-4-625-2011, 2011.

Wilson, J. C., Lafleu, B. G., Hilbert, H., Seebaugh, W. R., Fox, J., Gesler, D. W., Brock, C. A., Huebert, B. J., and Mullen, J.: Function and Performance of a Low Turbulence Inlet for Sampling Supermicron Particles from Aircraft Platforms, Aerosol Sci. Technol., 38, 790-802, doi:10.1080/027868290500841, 2004.

Yokelson, R. J., Crounse, J. D., DeCarlo, P. F., Karl, T., Urbanski, S., Atlas, E., Campos, T., Shinozuka, Y., Kapustin, V., Clarke, A. D., Weinheimer, A., Knapp, D. J., Montzka, D. D., Holloway, J., Weibring, P., Flocke, F., Zheng, W., Toohey, D., Wennberg, P. O., Wiedinmyer, C., Mauldin, L., Fried, A., Richter, D., Walega, J., Jimenez, J. L., Adachi, K., Buseck, P. R., Hall, S. R., and Shetter, R.: Emissions from biomass burning in the Yucatan, Atmos. Chem. Phys., 9, 5785-5812, doi:10.5194/acp-9-5785-2009, 2009.

Yokelson, R. J., Burling, I. R., Gilman, J. B., Warneke, C., Stockwell, C. E., de Gouw, J., Akagi, S. K., Urbanski, S. P., Veres, P., Roberts, J. M., Kuster, W. C., Reardon, J., Griffith, D. W. T., Johnson, T. J., Hosseini, S., Miller, J. W., Cocker III, D. R., Jung, H., and Weise, D. R.: Coupling field and laboratory measurements to estimate the emission factors of identified and unidentified trace gases for prescribed fires, Atmos. Chem. Phys., 13, 89-116, doi:10.5194/acp-13-89-2013, 2013. 